\title{
Effects of carbon dioxide pneumoperitoneum on hepatic and renal morphology of rats after segmental colectomy and colonic anastomosis ${ }^{1}$
}

\author{
Efeitos do pneumoperitônio com dióxido de carbono sobre a morfologia renal e hepática de \\ ratos submetidos à colectomia segmentar e anastomose colônica
}

\author{
Igor Eduardo Caetano Fariasi, Pedro Henrique Alves de Morais ${ }^{\mathrm{I}}$, Leonardo de Castro Durães ${ }^{\mathrm{II}}$, Fabiana Pirani Carneiro ${ }^{\mathrm{III}}$, \\ Paulo Gonçalves de Oliveira ${ }^{\text {IV }}$, João Batista de Sousa ${ }^{\text {IV }}$ \\ ${ }^{1}$ Research performed at Experimental Laboratory of Surgery and Laboratory Pathology, School of Medicine, Brasilia University (UnB), Brazil. \\ ${ }^{I}$ Graduate student, School of Medicine, UnB, Brasilia, Brazil. Acquisition, interpretation of data and manuscript writing. \\ ${ }^{\text {II }}$ Fellow PhD degree, Postgraduate Program in Medical Sciences, School of Medicine, UnB, Brasilia, Brazil. Acquisition, interpretation of data and \\ statistical analysis. \\ ${ }^{\text {III }} \mathrm{PhD}$, Associate Professor, Pathology, School of Medicine, UnB, Brasilia, Brazil. Acquisition, interpretation of data and critical revision. \\ IV PhD, Associate Professor, Clinical Surgery, School of Medicine, UnB, Brasilia, Brazil. Interpretation of data, statistical analysis, and critical \\ revision. \\ ${ }^{\text {IV }} \mathrm{PhD}$, Associate Professor, Clinical Surgery, School of Medicine, UnB, Brasilia, Brazil. Responsible for conception, design, intellectual and scientific \\ content of the study, analysis and interpretation of data, manuscript writing and critical revision.
}

\begin{abstract}
Purpose: To evaluate the effects of increased intraperitoneal pressure caused by carbon dioxide pneumoperitoneum on the hepatic and renal morphology of rats. Methods: Fifty-four adult male rats were randomly divided into three groups (P, PP and C) after anesthesia: $\mathrm{P}$ - in 18 animals, pneumoperitoneum was established for 30 minutes immediately before laparotomy; PP - in 18 animals, pneumoperitoneum was established for 60 minutes divided into 30 immediately before laparotomy and 30 after abdominal closure; control group (C) - 18 animals underwent laparotomy without pneumoperitoneum induction. The pneumoperitoneum was maintained at a pressure of $5 \mathrm{~mm} \mathrm{Hg}$. Nine animals in each group were killed on the $3^{\text {rd }}$ and $7^{\text {th }}$ postoperative days, when kidney and liver samples were collected for morphological analysis. The liver specimens were stained with hematoxylin and eosin (HE), and the kidney specimens, with HE and von Kossa. Blinded examiners analyzed the slides. Results: No changes in renal morphology were found. Liver samples showed histological signs of degeneration in animals in the pneumoperitoneum groups killed on the $7^{\text {th }}$ postoperative day $(\mathrm{p}=0.029$ ). Conclusion: The $\mathrm{CO}_{2}$ pneumoperitoneum did not affect renal morphology but caused hydropic degeneration in the liver of animals killed on the $7^{\text {th }}$ postoperative day.
\end{abstract}

Key words: Kidney. Liver. Pneumoperitoneum, Artificial. Carbon Dioxide. Laparoscopy. Rats.

\section{RESUMO}

Objetivo: Avaliar os efeitos do aumento de pressão intraperitonial causada pelo pneumoperitônio com dióxido de carbono na morfologia renal e hepática de ratos submetidos à colectomia segmentar a anastomose colônica. Métodos: 54 ratos machos da linhagem Winstar, que, após serem anestesiados, foram aleatoriamente distribuídos em três grupos (P, PP e C): P - 18 animais submetidos a pneumoperitônio por 30 minutos imediatamente antes da laparotomia PP - 18 animais submetidos a pneumoperitônio por 60 minutos, 30 imediatamente antes da laparotomia e 30 após a laparorrafia ; $\mathrm{C}$ - (grupo controle) - 18 animais submetidos à laparotomia sem o uso de pneumoperitônio. Os animais foram mortos no terceiro e sétimo dia pós-operatório, quando ocorreu a coleta do rim e parte do fígado. As peças foram coradas com Hematoxilina e Eosina e Von Kossa e analisadas por um patologista que desconhecia os grupos. Resultados: Não foram observadas alterações nas estruturas renais. Nas amostras hepáticas foram observados achados histológicos como a degeneração hidrópica no grupo de animais mortos no sétimo DPO $(p=0,029)$. Conclusão: O pneumoperitônio com dióxido de carbono não afetou a morfologia renal e causou a degeneração hidrópica no fígado dos animais mortos no $7^{\circ}$ dia pós-operatório.

Descritores: Rim. Fígado. Pneumoperitônio Artificial. Dióxido de Carbono. Laparoscopia. Ratos. 


\section{Introduction}

New diagnostic tools have been developed after the advent of laparoscopy, which substantially increased the number of minimally invasive surgeries. In addition to the benefits of this new technique, several questions have been raised about the possible secondary consequences of acute and prolonged gas insufflation and the resulting higher intraperitoneal pressures ${ }^{1}$.

The introduction of carbon dioxide under pressure into the peritoneal cavity may cause changes in the splanchnic microcirculation, which may affect pulmonary, cardiac, liver and kidney physiology $y^{1,2}$. Changes have also been found in intracranial pressure, blood acid-base control and the immune system (2).

Gas insufflation into the peritoneal cavity increases intra-abdominal pressure and, consequently, peripheral vascular resistance. This phenomenon seems to directly affect the capillary and capacitance vessels of the arterial and venous systems. The blood flow of intra-abdominal organs, except for the adrenal glands, gradually decreases until the pressure reaches about 20 $\mathrm{mmHg}$ in animal models $\mathrm{s}^{2,3}$.

In the special case of the kidneys, the compression of the aorta, the renal artery, the renal vein and the renal parenchyma is the hypothesis most often accepted to explain changes in renal function, such as renin release and reduced urine excretion ${ }^{4-6}$. Prolonged periods of pneumoperitoneum-induced ischemia may also be associated with morphological changes of renal components $^{5,6}$.

Similarly to the changes seen in the kidneys, hepatic functions are also affected by increased intra-abdominal pressure. The portal blood flow may be reduced in up to $65 \%$, and the arterial blood flow, in up to $45 \%$ when a pneumoperitoneum of $20 \mathrm{mmHg}$ is established in pigs ${ }^{1}$. Functional changes occur and elevate serum transaminase levels ${ }^{7}$, and the liver parenchyma may undergo morphological changes.

The use of laparoscopy has become routine in medical practice, and the experience with laparoscopic surgery has guided the study of its quantitative and qualitative benefits and drawbacks. Therefore, this study, whose aim was to improve the understanding of side effects of pneumoperitoneum in a surgical model, evaluated the effect of $\mathrm{CO}_{2}$ pneumoperitoneum on the hepatic and renal morphology of rats that underwent colonic anastomosis.

\section{Methods}

All procedures were performed under the guidelines of the Brazilian College of Animal Experimentation (COBEA). The study was approved by the Ethics Committee of Animal Use (CEUA), UnB.

Fifty-four male Wistar rats, mean age of 90 days and weight of $285 \mathrm{~g}$ to $387 \mathrm{~g}$ were obtained from the Bioagri Laboratory of Brasília. The animals were weighed using a precision scale.

All animals were anesthetized with $10 \mathrm{mg} / \mathrm{kg} \mathrm{IM}$ xylazine hydrochloride and $75 \mathrm{mg} / \mathrm{kg}$ IM ketamine hydrochloride. Anesthesia was verified by reflex testing of withdrawal to painful stimuli and additional doses of anesthetic drugs were administered whenever anesthetic recovery occurred.

Pneumoperitoneum was established using a laparoscopic insufflator. After abdominal puncture with a Veress needle, $\mathrm{CO}_{2}$ was introduced at a flow rate of 0.5 to 1.0 liter per minute, without preheating, until pressure stabilization was achieved at $5 \mathrm{mmHg}$.

The animals were randomly divided into 3 groups (P, PP and C) of 18 animals each:

Group P - pneumoperitoneum was established 30 minutes immediately before laparotomy.

Group PP - pneumoperitoneum was established for 60 minutes, 30 immediately before laparotomy and 30 after abdominal wall closure.

Group C (Control group ) - no pneumoperitoneum.

Each group was subdivided into two subgroups of 9 animals each (P3, PP3, C3 and P7, PP7, C7) according to the dates scheduled for sacrifice: $3^{\text {rd }}$ and $7^{\text {th }}$ postoperative days (POD).

After anesthesia, each animal was placed on the surgical board in supine position with its fore and hind limbs fixed in abduction. The anterior abdominal region was shaved and cleaned with povidone-iodine.

A midline incision of about $5 \mathrm{~cm}$ was made, and all animals underwent resection of a $1 \mathrm{~cm}$ colonic segment at $2.5 \mathrm{~cm}$ to $3.5 \mathrm{~cm}$ proximal to the peritoneal reflection. The colonic transit was reconstructed using end-to-end anastomosis and single-layer continuous suture with 6-0 polypropylene suture.

On the $3^{\text {rd }}$ and $7^{\text {th }}$ postoperative day, nine animals in each group were anesthetized and underwent another laparotomy for macroscopic evaluation of the peritoneal cavity and colonic anastomosis. The left kidney and right lobe of the liver from each rat were collected. Then, the animals were killed by an overdose of thiopental injected into the inferior vena cava.

\section{Histological examination}

Specimens were stored in $10 \%$ formalin for histopathological analysis. The slides were stained with hematoxylin and eosin (HE), as well as with Von Kossa to analyze possible renal morphological changes.

A pathologist blinded to group and subgroup distributions performed the histological analyses of slides using light microscopy.

The following renal morphology factors were analyzed: hydropic degeneration, congestion, cytoplasmic vacuoles, cytoplasmic membrane rupture and necrosis.

In the analysis of liver specimens, the following morphological changes were analyzed: hepatic steatosis, necrosis and hydropic degeneration.

These changes were classified according to the degree of lesions found: mild steatosis and moderate steatosis; mild hydropic degeneration and moderate hydropic degeneration; and focal necrosis.

\section{Statistical analysis}

The Special Package for Social Sciences (SPSS) version 16.0 was used for data analysis. The Fisher exact test was used for comparisons. The level of significance was set at $5 \%(\mathrm{p}<0.05)$. 


\section{Result}

\section{Overall findings}

During postoperative observation, no animals had any clinical complications and all survived until the dates scheduled for sacrifice.

\section{Renal morphology}

The analysis of renal morphological changes revealed that there was no ischemia or hydropic degeneration, congestion, cytoplasmic vacuoles, cytoplasmic membrane rupture or necrosis in collected HE-stained specimen. Changes found in the Von Kossa-stained specimens suggested calcification in the renal tubules $(p=0.124)$ in five animals on the $3^{\text {rd }}$ POD: 2 in the P3 group, two in the PP3 group and one in the C Group. On the $7^{\text {th }}$ POD, one specimen of the $\mathrm{C}$ group showed calcification (Table 1).

TABLE 1 - Frequency of tubular calcification in animals of the 3 groups ( $\mathrm{P}, \mathrm{PP}$ and $\mathrm{C}$ ) at both time points (3 and 7 days) - subgroups P3, P7, PP3, PP7, C3, C7): P Group pneumoperitoneum for 30 minutes before laparotomy (P3, P7); PP Group - pneumoperitoneum for 30 minutes before laparotomy and 30 minutes after abdominal closure (PP3, PP7); C Group - control without pneumoperitoneum (C3, C7).

\begin{tabular}{ccccccc}
\hline \multirow{2}{*}{ Calcification } & \multicolumn{7}{c}{ Groups } & And & Subgroups & \\
\cline { 2 - 7 } Present & P3 & PP3 & C3 & P7 & PP7 & C7 \\
\hline Absent & 7 & 7 & 8 & 9 & 9 & 8 \\
\hline Total & 9 & 9 & 9 & 9 & 9 & 9 \\
\hline
\end{tabular}

\section{Hepatic morphology}

The analysis of morphological changes revealed that liver samples had hepatic steatosis and hydropic degeneration (Figures 1 and 2).

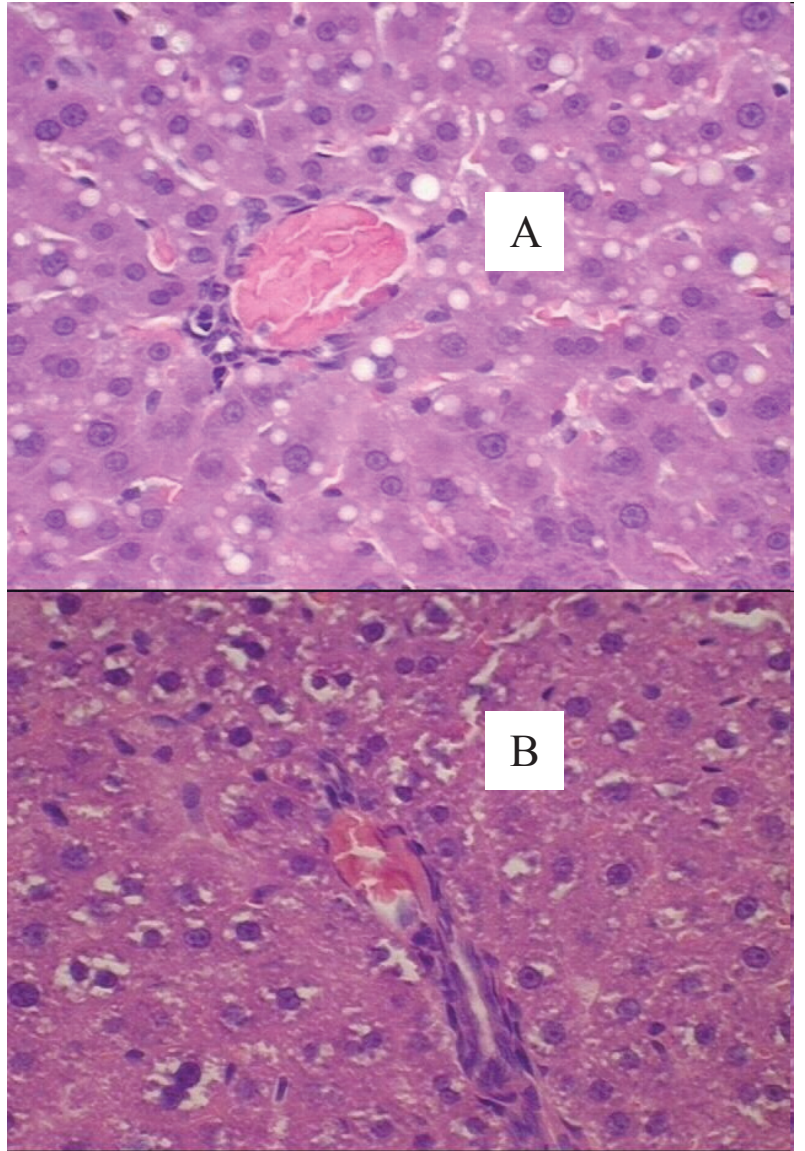

FIGURE 1 - Histological liver sections (HE, 400X). A. Hepatocytes with microvesicular steatosis (intracytoplasmic vacuoles). B. Cellular swelling (hydropic degeneration) in hepatocytes.

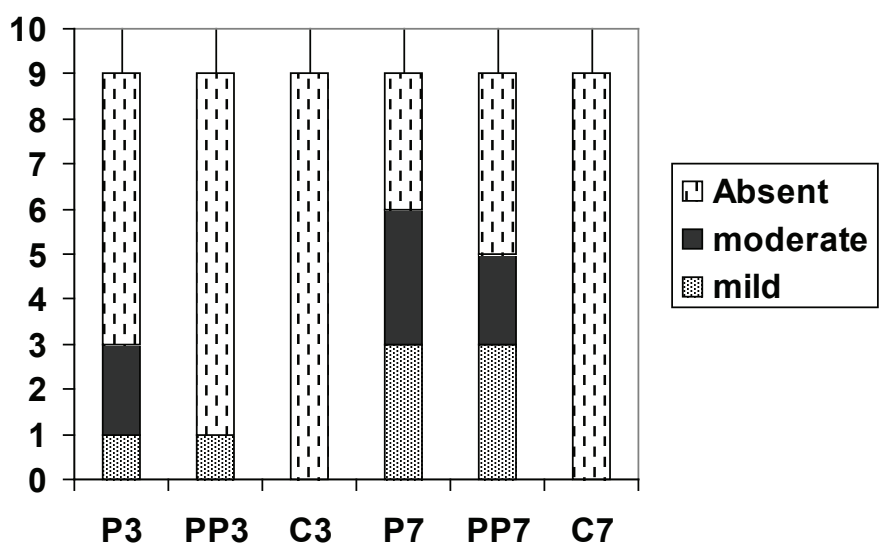

FIGURE 2 - Frequency of hydropic degeneration in the animals of the 3 groups (P, PP and $\mathrm{C}$ ) at both time points ( 3 and 7 days) - subgroups $\mathrm{P} 3, \mathrm{P} 7$, PP3, PP7, C3, C7): P Group - pneumoperitoneum for 30 minutes before laparotomy (P3, P7); PP Group- pneumoperitoneum for 30 minutes before laparotomy and 30 minutes after suture (PP3, PP7); C Group control without pneumoperitoneum $(\mathrm{C} 3, \mathrm{C} 7)$.

P3, PP and C3 $(\mathrm{p}=0.354) \quad$ P7 and PP7 $(\mathrm{p}=1.00)$

P7 and C7 $(p=0.009) \quad$ PP7 and C7 $(p=0.029)$ 
Of the animals killed on the $3^{\text {rd }}$ POD, 3 in the P3 group had steatosis, (2 mild, 1 moderate); 7 in the PP3 group had steatosis (5 mild, 2 moderate); in the $\mathrm{C} 3$ group, 4 had steatosis (4 mild) (p $=0.254)$ (Table 2).

TABLE 2 - Frequency of hepatic steatosis in animals of the 3 groups at both time points (3 and 7 days) - subgroups P3, P7, PP3, PP7, C3, C7): P Group - pneumoperitoneum for 30 minutes before laparotomy (P3, P7); PP Group- pneumoperitoneum for 30 minutes before laparotomy and 30 minutes after suture (PP3, PP7); C Group - control without pneumoperitoneum (C3, C7).

\begin{tabular}{ccccccc}
\hline \multirow{2}{*}{ Steatosis } & \multicolumn{7}{c}{ Groups } & And & Subgroups & & \\
\cline { 2 - 7 } & $\mathbf{P 3}$ & $\mathbf{P P 3} *$ & $\mathbf{C 3} *$ & $\mathbf{P 7} * *$ & $\mathbf{P P 7} * *$ & $\mathbf{C 7} * *$ \\
\hline Mild & 2 & 5 & 4 & 2 & 1 & 1 \\
\hline Moderate & 1 & 2 & 0 & 1 & 2 & 5 \\
\hline Absent & 6 & 2 & 5 & 6 & 6 & 3 \\
\hline Total & 9 & 9 & 9 & 9 & 9 & 9 \\
\hline
\end{tabular}

$*(\mathrm{p}=0.254) * *(\mathrm{p}=0.340)$

Hydropic degeneration was found in 4 animals: 1 in the PP3 subgroup (1 mild); and 3 in the P3 group (1 mild, 2 moderate) $(\mathrm{p}=0.354)($ Table 3$)$.

In the subgroup of animals killed on the $7^{\text {th }}$ POD, steatosis was found in 3 animals in the PP7 group (all mild), 3 in the P7 group ( 2 mild, 1 moderate), and 6 in the $C$ group ( 5 moderate, 1 mild) $(\mathrm{p}=0.340)$ (Table 2$)$. Hydropic degeneration occurred in 11 animals: 6 in the P7 subgroup ( 3 mild and 3 moderate; 5 in the PP7 group ( 3 mild, 2 moderate) $(\mathrm{p}=0.024)$. When subgroups were compared to each other, no differences between P7 and PP7 were found $(p=1.00)$. There were statistically significant differences between the C7 and P7 subgroups ( $p=0.009)$ and between the PP7 and C7 subgroups $(\mathrm{p}=0.029)$ (Table 3 and Figure 2).

TABLE 3 - Frequency of hydropic degeneration in the animals of the 3 groups (P, PP and $\mathrm{C})$ at both time points $(3$ and 7 days) - subgroups P3, P7, PP3, PP7, C3, C7): P Group pneumoperitoneum for 30 minutes before laparotomy (P3, P7); PP Group- pneumoperitoneum for 30 minutes before laparotomy and 30 minutes after suture (PP3, PP7); C Group - control without pneumoperitoneum (C3, C7).

\begin{tabular}{ccccccc}
\hline \multirow{2}{*}{$\begin{array}{c}\text { Hydropic } \\
\text { Degeneration }\end{array}$} & \multicolumn{7}{c}{ Groups } & And & Subgroups & \\
\cline { 2 - 7 } & P3 & PP3 & C3 & P7 & PP7 & C7 \\
\hline Mild & 1 & 1 & 0 & 3 & 3 & 0 \\
\hline Moderate & 2 & 0 & 0 & 3 & 2 & 0 \\
\hline Absent & 6 & 8 & 9 & 3 & 4 & 9 \\
\hline Total & 9 & 9 & 9 & 9 & 9 & 9 \\
\hline
\end{tabular}

$\mathrm{P} 3$, PP and $\mathrm{C} 3(\mathrm{p}=0.354)$

$\mathrm{P} 7$ and $\mathrm{C} 7(\mathrm{p}=0.009)$

\section{Discussion}

Laparoscopic procedures produce higher intraperitoneal pressures and result in oliguria in both animals and human beings $^{8}$. Decreased blood flow and abnormal glomerular filtration and tubular functions are major consequences of a pneumoperitoneum ${ }^{1,6}$.

In addition, hormonal changes centrally and peripherally coordinated lead to greater releases of renin, angiotensin and vasopressin, which act together during episodes of increased intraperitoneal pressure and affect renal activity ${ }^{9}$.

Positive intraperitoneal pressures also cause increases in sympathetic activity regulated by baroreceptors and mediated by the effects of hypercapnia, which may lead to renal cortical vasoconstriction and its sequelae ${ }^{10,11}$.

Changes in renal blood flow within the cortex and the renal medulla promote the changes discussed above $e^{6,11-13}$. All these factors are combined with surgical stress and the effects of anesthetic drugs, which act directly on cardiovascular and renal functions ${ }^{14}$.

The physiopathology of renal dysfunction under conditions of high intra-abdominal pressure is multifactorial and complex. Hemodynamic and hormonal mechanisms, as well as inflammatory changes, may lead to renal dysfunction ${ }^{5}$. These phenomena are associated with reduced cardiac output and the compression of veins, arteries and renal parenchyma ${ }^{3,6}$. Such changes are usually transient and disappear soon after pneumoperitoneum cessation.

The analysis of data in the literature suggests that, although functional changes may be caused by an elevated intraabdominal pressure, they are not always followed by significant renal morphological changes, which, when they occur, are transient ${ }^{12,13}$.

Ozmen et al. ${ }^{14}$ conducted a histological analysis of kidneys after exposure to high pressures and found reversible cell damage as a result of hypoxia, such as acute cellular swelling, cytoplasmic vacuoles and hydropic degeneration. They also found early changes suggestive of irreversible injury, such as rupture of the cytoplasmic membrane, focal hemorrhage and epithelial cells within the tubular lumens. However, in experimental studies using intra-abdominal pressures below $15 \mathrm{mmHg}$, no evidence of significant long-term renal histological changes has been found ${ }^{12,13}$. These findings were partly reproduced in our study, as no histological or morphological changes caused by $\mathrm{CO}_{2}$ pneumoperitoneum were found. The low pressure $(5 \mathrm{mmHg})$ used in the peritoneal cavity of animals might not explain these results, as this value corresponds, in rats, to the intra-abdominal pressure used during laparoscopy in human beings in clinical practice ${ }^{14}$

Morphological changes may also be associated with exposure time to pneumoperitoneum which, in our study, may not have been long enough to result in changes in renal structures. However, when a pressure of $5 \mathrm{mmHg}$ was used, there was production of 8-iso-prostaglandin F2 (8-iso-PGF2), which may lead to kidney damage due to reperfusion after ischemic periods $^{14-16}$.

The calcification in the samples collected in this study may be explained by two possible causes. The first is associated 
with genetic factors that lead to greater accumulations of calcium and are more pronounced in old animals ${ }^{17}$. The second is associated with diet composition. Diets with low magnesium contents $(\mathrm{Mg})$ or low calcium-to-phosphorus ratios $(\mathrm{Ca}: \mathrm{P})$ may induce the development of nephrocalcinosis ${ }^{17}$. In our study, nephrocalcinosis was not the result of pneumoperitoneum, as its distribution in animals of the 3 groups was not statistically significant $(p>0.05)$.

The effects of increased abdominal cavity pressure on liver structures are different and directly associated with hemodynamic changes. When the liver is exposed to high intraperitoneal pressures, the splanchnic circulation becomes more difficult and generates regions of hypoperfusion or ischemia. This fact is exacerbated by the compression of vessels of the portal system, which further reduces the blood supply to liver cells ${ }^{18}$.

Changes in liver blood flow are also associated with the sympathetic and humoral systems, triggered by hypercapnia and by increased intraperitoneal pressure ${ }^{10}$.

The use of anesthetic drugs reduces cardiac output and blood supply to the liver ${ }^{19}$. These hemodynamic changes are followed by changes in hepatic functions.

Previous studies showed that the decrease in liver blood flow during pneumoperitoneum in pigs and dogs is associated with changes in hepatic function. This fact explains the increase of aspartate aminotransferase (AST), which is an indicator of liver damage, at the pressure of $6 \mathrm{mmHg}^{1}$.

In other studies with intra-abdominal pressures of 10 $\mathrm{mmHg}$, changes in serum levels of other indicators of hepatic function, such as the levels of aminotransferase, alkaline phosphatase, gamma-glutamyl transpeptidase and lactic dehydrogenase, have also been reported ${ }^{7}$.

Therefore, pneumoperitoneum may affect hepatic functions, and its effect is directly associated with exposure time and pressure levels. However, the effect of high pressures was transient in both clinical and laboratory studies, and most functional changes disappeared $72 \mathrm{~h}$ after deflation ${ }^{1,7}$.

The hepatic changes found in this study confirm some of the possible abnormalities caused by ischemia of hepatic tissue. Hydropic degeneration, a reversible lesion found in the specimens analyzed in this study, may be explained mainly by decreased portal blood flow during exposure to pneumoperitoneum, either by vascular compression or decreased venous return due to the high intra-abdominal pressure ${ }^{19}$.

The lesions found in both postoperative periods (POD3 and POD7) are in agreement with those reported in previous studies, in which the liver had periods of ischemia and reperfusion ${ }^{19-21}$. In addition to ischemic events during gas insufflation, other factors, such as the use of anesthetic drugs and the presence of toxins, also trigger vacuolar degeneration.

The reduction of microcirculation causes changes in immune responses, as well as in Kupffer cells and hepatocyte energy metabolism ${ }^{20}$.

Recent studies found alternative explanations to changes in both hepatic function and morphology. Ozmen et al..$^{14}$ found that, in addition to hemodynamic changes, lesions in liver cells were caused by reperfusion of organs during pneumoperitoneum.

Ischemia and reperfusion induce the release of inflammatory mediators that lead to lipid peroxidation and produce a series of oxygen-derived free radicals ${ }^{21,22}$. This not only makes the injury worse, but also generates further tissue changes (14). The production of free radicals depends on the degree of ischemia in tissues and is correlated with the pressure and duration of pneumoperitoneum ${ }^{14}$.

Another factor that affects the hepatic blood flow is the production of inflammatory cytokines as a result of increased immune activity of liver cells. In the liver microcirculation, there is a large number of leukocytes and platelets adhered to the endothelium and an increased activity of Kupffer cells, which leads to increased production of pro-inflammatory substances with a marked degree of tissue ischemia ${ }^{23}$.

The hepatic steatosis found in the samples collected in our study may have different etiologies. If the diet of the animals were rich in fatty acids, the metabolic changes and the emergence of these changes might be more likely ${ }^{24}$. However, the diet offered to the animals in this study was a standard diet for laboratory animals.

Lipid accumulation within hepatocytes has been linked to increased susceptibility of liver tissue to ischemia and reperfusion, which makes the liver with steatosis more sensitive to situations that require blood flow reduction ${ }^{25}$. However, this change becomes more significant under conditions in which steatosis is more serious, which was not the case in our study samples ${ }^{25}$

The presence of lesions in the liver parenchyma shows that acute increases of the peritoneal cavity pressure may induce the appearance of abnormal tissue. Therefore, the dysfunction caused by gas insufflation into the abdominal cavity may intensify pre-existing pathologies, such as kidney and liver failure ${ }^{1,7}$.

Significant clinical changes may affect elderly patients or those with cardiac problems who have to undergo prolonged laparoscopic procedures. The choice of type of abdominal surgery should be carefully analyzed when the patient has impaired kidney or liver function. If the choice is laparoscopy, pressure and duration of the procedure are important points to consider ${ }^{1,14,15}$.

\section{Conclusion}

The $\mathrm{CO}_{2}$ pneumoperitoneum did not affect renal morphology, but caused changes in hepatic morphology as it led to hydropic degeneration.

\section{References}

1. Fagundes MAF, Montero EFS, Novo NF, Bandeira COP. Efeitos do pneumoperitônio em ratos. Acta Cir Bras. 2001;23:703-7.

2. Grabowski JE, Talamini MA. Physiological effects of pneumoperitoneum. J Gastrointest Surg. 2009;13:1009-6.

3. Quevedo L, Revilla B, Sanz S, Romero Z, Santos P, Letosa M, Sánchez C, Gorospe C. Análisis comparativo de las modificaciones hemodinámicas y del flujo sanguíneo renal (FSR) durante la nefrectomía abierta y laparoscópica: modelo experimental. Actas Urol Esp 2007;31:382-93.

4. Chiu AW, Chang LS, Birkett DH, Babayan RK. The impact of pneumoperitoneum, pneumoretroperitoneum, and gasless laparoscopy on the systemic and renal hemodynamics. J Am Coll Surg. 1995; 181:397-406.

5. Wauters J, Claus P, Brosens N, McLaughlin M, Malbrain M, Wilmer A. Pathophysiology of renal hemodynamics and renal cortical 
microcirculation in a porcine model of elevated intra-abdominal pressure. J Trauma. 2009;66:713-9.

6. Demyttenaere S, FeldmanLS, Fried GM.Effect of pneumoperitoneum on renal perfusion and function: a systematic review. Surg Endosc. 2007;21:152-60.

7. Chida VV, Moreira MB, Leme LFP, Fagundes DJ, Ramalho CEB, Novo NF, Montero EFS. Estudo da função hepática de ratos espontaneamente hipertensos submetidos a diferentes pressões de pneumoperitônio com CO2. Acta Cir Bras. 2003;18:51-8.

8. Santos LS, Filho RT, Figueiredo TMS, Cravo G. Effects of the pneumoperitoneum in rats submitted to a unilateral nephrectomy: morphologic and functional study on the remnant kidney Acta Cir. Bras. 2005;20:195-9.

9. Gudmundsson FF, Viste A, Myking OL. Role of angiotensin II under prolonged increased intraabdominal pressure (IAP) in pigs. Surg Endosc. 2003;17:1092-7.

10. Bickel A, Yahalom M, Roguin N. Power spectral analysis of heart rate variability during positive pressure pneumoperitoneum: the significance of increased cardiac sympathetic expression. Surg Endosc. 2002;16:1341-4.

11. Chiu AW, Azadzoi KM, Hatzichristou DG, Siroky MB, Krane RJ, Babayan RK. Effects of intra-abdominal pressure on renal tissue perfusion during laparoscopy. J Endourol. 1994;8:99-103.

12. Hazebroek EJ, Bruin RWF, Bouvy ND, Marquet RL, Bonthuis F, Bajema IM, Hayes DP, Ijzermans JNM, Bonjer HJ. Longterm impact of pneumoperitoneum used for laparoscopic donor nephrectomy on renal function and histomorphology in donor and recipient rats. Ann Surg. 2003;237:351-7.

13. Lee BR, Cadeddu JA, Molnar-Nadasdy G. Chronic effect of pneumoperitoneum on renal histology. J Endourol. 2009;13:279-82.

14. Ozmen MM, Zulfikaroglu B, Besler TH, Cinel L, Cinel I. The correlation between reactive oxygen species and histopathology of the liver, gut, and kidneys in animals with elevated intra-abdominal pressure. J Laparoendosc Adv Surg Tech A. 2009;19:339-43.

15. Avital S, Itah R, Szomstein S, Rosenthal R, Inbar R, Sckornik Y, Weinbroum A. Correlation of $\mathrm{CO} 2$ pneumoperitoneal pressures between rodents and humans. Surg Endosc. 2008;23:50-4
16. Bentes de Souza AM, Wang CC, Chu CY. The effect of intraabdominal pressure on the generation of 8-iso-prostoglandin F2alpha during laparoscopy in rabbits. Hum Reprod 2003;18:21818.

17. Stonard MD, Samuels DM, Lock EA. The pathogenesis and effect on renal function of nephrocalcinosis induced by different diets in female rats. Food Chem Toxicol. 1984;22:139-46.

18. Mogilner J, Sukhotnik I, Brod V, Hayari L, Coran AGC, Shiloni E, Eldar S, Bitterman A. Effect of elevated intra-abdominal pressure on portal vein and superior mesenteric artery blood flow in a rat. J Laparoendosc Adv Surg Tech A. 2009;19 Suppl1:S59-62.

19. Diebel LN, Wilson RF, Dulchavsky SA, Saxe J. Effect of increased intraabdominal pressure on hepatic arterial, portal venous, and hepatic microcirculatory blood flow. J Trauma. 1992;33:279-82.

20. Richter S, Olinger A, Hildebrandt U, Menger MD, Vollmar B. Loss of physiologic hepatic blood flow control ("hepatic arterial buffer response") during CO2 pneumoperitoneum in the rat. Anesth Analg. 2001;93:872-7.

21. Schmidt SC, Schumacher G, Klage N, Chopra S, Neuhaus P, Neumann U. The impact of carbon dioxide pneumoperitoneum on liver regeneration after liver resection in a rat model. Surg Endosc. 2010;24:1-8

22. Pross M, Schulz HU, Flechsig A, Manger T, Halangk W, Augustin W, Lippert H, Reinheckel T. Oxidative stress in lung tissue induced by CO2 pneumoperitoneum in the rat. Surg Endosc. 2000;14:1180 4.

23. Salcedo MM, Catafau JR, Prieto J, Ávila MA, Peralta C. The response of the hepatocyte to ischemia. Liver Int 2007;6:6-15.

24. Bradbury MW, Berk PD. Lipid metabolism in hepatic steatosis. Clin Liver Dis. 2004;8:639-71.

25. Soltys K, Dikdan G, Koneru B. Oxidative stress in fatty livers of obese Zucker rats: rapid amelioration and improved tolerance to warm ischemia with tocopherol. Hepatology. 2001;34:13-8.

\section{Correspondence:}

João Batista de Sousa

Campus Universitário Darcy Ribeiro

Prédio da Reitoria, $2^{\circ}$ pavimento, sala B2-16

70910-900 Brasília-DF Brasil

Tel: (55 61)3307-2201

sousajb@unb.br
Conflict of interest: none Financial source: none

Received: December 10, 2010 Review: February 16, 2011 Accepted: March 17, 2011 